\title{
Geociências
}

\section{Distribution and sources of polycyclic aromatic hydrocarbons in the aquatic environment: a multivariate analysis}

\author{
(Distribuição e origem de hidrocarbonetos policíclicos \\ aromáticos nos ambientes hídricos: uma análise multivariada)
}

\author{
Joil José Celino \\ Dr. em Geologia Regional \\ Laboratório de Estudos do Petróleo \\ (LEPETRO) - Núcleo de Estudos \\ Ambientais (NEA), Instituto de \\ Geociências da UFBA (IGEO/UFBA) \\ E-mail: joil@ufba.br
}

Henry Xavier Corseuil

Dr. em Engenharia Ambiental Laboratório de Remediação de Águas Subterrâneas (REMAS)

Departamento de Engenharia Sanitária e Ambiental - Universidade Federal de Santa Catarina (UFSC)

E-mail:corseuil@ens.ufsc.br

\section{Marilda Fernandes}

Dra. em Química Analítica Laboratório de Remediação de Águas Subterrâneas (REMAS)

- Departamento de Engenharia Sanitária e Ambiental - Universidade Federal de Santa Catarina (UFSC)

E-mail:marilda@ens.ufsc.br

\section{Karina Santos Garcia \\ MSc. em Geoquímica e Meio Ambiente \\ Laboratório de Estudos do Petróleo (LEPETRO) - Núcleo de Estudos Ambientais (NEA), Instituto de Geociências da UFBA (IGEO/UFBA) E-mail:garciaks@ufba.br}

\section{Resumo}

Nesse trabalho, 14 dos hidrocarbonetos policíclicos aromáticos (HPA) incluídos pelo Environmental Protection Agency (EPA) na lista de poluentes prioritários foram analisados através de cromatografia gasosa com espectrometria de massas acoplada (GC-MS). A amostragem das águas superficiais foi realizada no estuário do rio Paraguaçu e do rio Jaguaripe (Bahia), nordeste do Brasil. Concentrações totais de HPAs variaram de 0,0029 a 0,1079 ng/L em águas superficiais (rios principais, afluentes), com valor médio de $0,0344 \mathrm{ng} / \mathrm{L}$. Tais concentrações podem ser tomadas como valores-base para a região estudada. Os perfis de HPAs foram dominados por HPAs de baixo peso molecular (dois ou três anéis de componentes) em amostras de água superficial. Isto é indicativo de sua origem a partir de óleo ou contaminação residual (entrada petrogênica). Os dados recolhidos mostram que entrada petrogênica foi predominante em quase todas as estações investigadas. Para discriminar diferenças e semelhanças entre as amostras, a análise de componente principal (ACP) foi realizada utilizando uma matriz de correlação. A ACP revelou as relações entre todas as águas superficiais das estações investigadas.

Palavras-chave: Hidrocarbonetos policíclicos aromáticos (HPA), água superficial, fonte, cromatografia à gás-espectrometria de massas (CG-EM), análise da componente principal (ACP).

\begin{abstract}
Fourteen polycyclic aromatic hydrocarbons (PAHs) included in the US Environmental Protection Agency's (EPA) priority pollutant list were analyzed using gas chromatography-mass spectrometry (GC-MS). Surface water sampling was undertaken in the Paraguaçu Estuary (Bahia), northern Brazil. Total PAH concentrations varied from 0.0029 to $0.1079 \mathrm{ng} / \mathrm{L}$ in the surface waters (main rivers, tributaries) with a mean value of $0.0344 \mathrm{ng} / \mathrm{L}$. Such concentrations can be taken as background values for the studied region. The PAH profiles were dominated by low molecular weight PAHs (two- and three-ring components) in surface water samples. It indicated that PAHs in surface water may have its origin from oil or sewage contamination (petrogenic input). The collected data showed that petrogenic input was predominant at almost all the stations investigated.
\end{abstract}


To discriminate pattern differences and similarities among the samples, a principal component analysis (PCA) was performed using a correlation matrix. PCA revealed the latent relationships among all the surface water from the investigated stations.

Keywords: Polycyclic aromatic hydrocarbons (PAHs), surface water, source, gas chromatography-mass spectrometry (GC$M S)$, principal component analysis (PCA).

\section{Introduction}

Water pollution by organic compounds, many of which are known to be toxic or carcinogenic, has caused considerable and worldwide concern. Polycyclic aromatic hydrocarbons (PAHs), hydrocarbons containing two or more fused benzene rings, are a group of ubiquitous organic pollutants of great environmental concern because of the documented carcinogenicity in experiments with animals and the widespread occurrence of several of its members (Manoli et al., 2000). Due to their ubiquitous occurrence, recalcitrance and suspected carcinogenicity and mutagenicity, PAHs are included in the U.S. Environmental Protection Agency (EPA) and in the European Union priority lists of pollutants. The US EPA fixed 16 parent PAHs as priority pollutants, the latest being effective as of 1997 (Baumard et al, 1997; Mastral and Call'en, 2000; Magi et al., 2002; Szolar et al., 2002; Schubert et al., 2003). Some of these are considered to be possible or probable causes for human carcinogens and the endocrine disrupting activities of PAHs have been recently reported (Clemons et al., 1998; Brun et al., 2004). Therefore, their distributions in the environment and potential human health risks have become the focus of much attention.

The Todos os Santos Bay (TSB), located in northeastern Brazil, is the second largest coastal bay in the country (Figure 1), after São Marcos Bay. The three main drainage basins convey an average of $120 \mathrm{~m}^{3} / \mathrm{s}$ of freshwater into the Bay, but majority of this flow has been hindered by a dam in Paraguaçu River since 1985. The original average freshwater inflow was two orders of magnitude smaller than the estimated tidal discharge through the main Bay entrance. The Bay's oceanographic characteristics, as indicated by salinity measurements, are clearly marine (Lessa et al., 2001).

The tides are semi-diurnal, and are amplified up the Bay by a factor of 1.5 . Shallow water constituents become more important as the tide propagates along the Paraguaçu Channel and Paraguaçu River, where they generate time asymmetries that change between spring and neap tides. Currents are mainly bi-directional, and are stronger during the ebbing tide in most of the Bay. Offshore, relatively strong tidal currents appear to be felt in a radius of about $10 \mathrm{~km}$, where they are superimposed on wind-driven currents orientated to the southwest (Lessa et al., 2001).
The Paraguaçu Estuary, in the Maragojipe region, is part of the Todos os Santos Bay, which covers an area of around $1200 \mathrm{~km}^{2}$ (Figure 1); water depth reaches $6 \mathrm{~m}$ except in navigation channels (9-11 $\mathrm{m}$ depth). The Paraguaçu and Jaguaripe estuaries are micro tidal environments and its hydrodynamics are controlled mainly by ocean flow (Leão \& Dominguez, 2000). Water temperature distribution in the Paraguaçu Estuary, presents a warm season from December to March.

Three main watersheds drain into the TSB, namely the Paraguaçu, Subaé and Jaguaribe rivers (Figure 1), with long term average discharges of $112 \mathrm{~m}^{3} / \mathrm{s}, 7.7 \mathrm{~m}^{3} / \mathrm{s}$ e $0.32 \mathrm{~m}^{3} / \mathrm{s}$, respectively (CEPLAB, 1979, Wolgemuth et al., 1981). The first two empty into the northern and western margins of the TSB, whereas the third debauches very close to the mouth of the Itaparica Channel. These rivers probably have a minor impact on the oceanographic conditions inside the TSB (Lessa et al., 2001).

A majority of the surveys worldwide have been mainly focused on seawater (coastal of offshore) and estuarine water. However, little data is available for the PAH contamination of the inland waters of TSB, which usually acts as a receptor for sewage, industrial effluents and urban or rural run off (Celino \& Queiroz, 2006). As streams and rivers, lakes and ponds are frequently used for potable water supply and water reuse is common, contamination of water sources is particularly undesirable (Manoli \& Samara, 1999).

In Brazil, very limited studies for the monitoring of PAHs on surface water are performed (CETESB, 1979; CETESB, 1981; CETESB, 1990; CETESB, 2001; CRA, 2004). In order to evaluate the contamination status of PAHs in surface water from the estuarine region and aquatic environment, northern Brazil, an investigation has been performed with a quantitative GC-MS method.

\section{Materials and methods 2.1 Chemicals}

Standard PAHs (16 compounds specified on EPA Method 610 , each at $100,200,1000$ or $2000 \mathrm{ng} / \mathrm{mL}$ ) in a mixture were obtained from Supelco (Bellefonte, PA, USA). These compounds are as follows: naphthalene (Np), metil-naphthalene $(\mathrm{mNp})$, dimetil-naphthalene ( $\mathrm{dNp})$, acenaphthylene (Acy), acenaphthene (Ace), fluorine $(\mathrm{F})$, phenanthrene $(\mathrm{Ph})$, anthracene (An), fluoranthene (Fl), pyrene (Py), chrysene (Chry), benzo[a]anthracene (BaAn), benzo[b]fluoranthene $(\mathrm{BbFl})$, benzo[k]fluoranthene (BkFl), benzo[a]pyrene (BaPy), benzo[g,h,i]perylene (B[ghi]Pe) and dibenzo[a,h]anthracene $(\mathrm{dB}[\mathrm{ah}] \mathrm{An})$. Internal deuteration standards for naphthalene-d8, acenaphthene-d10, phenanthrened 10 and chrysene-d12 were obtained from Sigma-Aldrich. 
Working standards of PAHs were prepared by combining the standard mixture with the corresponding IS stock solution, respectively. These solutions were further diluted with dichloromethane to prepare calibration solutions in the range $0.0001-0.0010 \mathrm{ng} / \mu \mathrm{L}$. All solvents used for sample processing and analyses (dichloromethane, ethyl acetate, acetone, hexane and methanol) were of analytical grade and further distilled twice to remove impurities.

\subsection{Area description and sampling}

Todos os Santos Bay (TSB) is situated in the Northeast of Brazil. With a population of almost 2.1 million and the surface area of the Bay about $1.052 \mathrm{~km}^{2}$, it is a huge commercial and industrial center.

The bay receives municipal effluents (discharged either untreated or with only primary treatment) of 1.5 million people (São Francisco do Conde, Cachoeira, Santo Amaro and Feira de Santana cities). In addition, it is the receptor of multiple industrial discharges including those of a metallurgic centre from the City of Santo Amaro and a major petroleum refinery Landulfo Alves - Mataripe (LAM) (Figure 1). To date, information regarding the local pollution level and its effects is very limited (Veiga, 2003).

There are mainly two rivers flowing into TSB: Paraguaçu River and Jaguaripe River. Surface water samples $(2.0 \mathrm{~L})$ were collected $(0-10 \mathrm{~cm})$ by using cylinder samplers aboard a chartered vessel during axial surveys in February and July, 2007, and the nine locations of the sampling sites of surface water are shown in Figure 1. Samples were taken using precleaned and ashed glass bottles. Throughout the survey, a global positioning system was used to locate the sampling positions, and various sensors, including ones for conductivity, temperature and depth, were deployed for obtaining these master variables (Table 1).

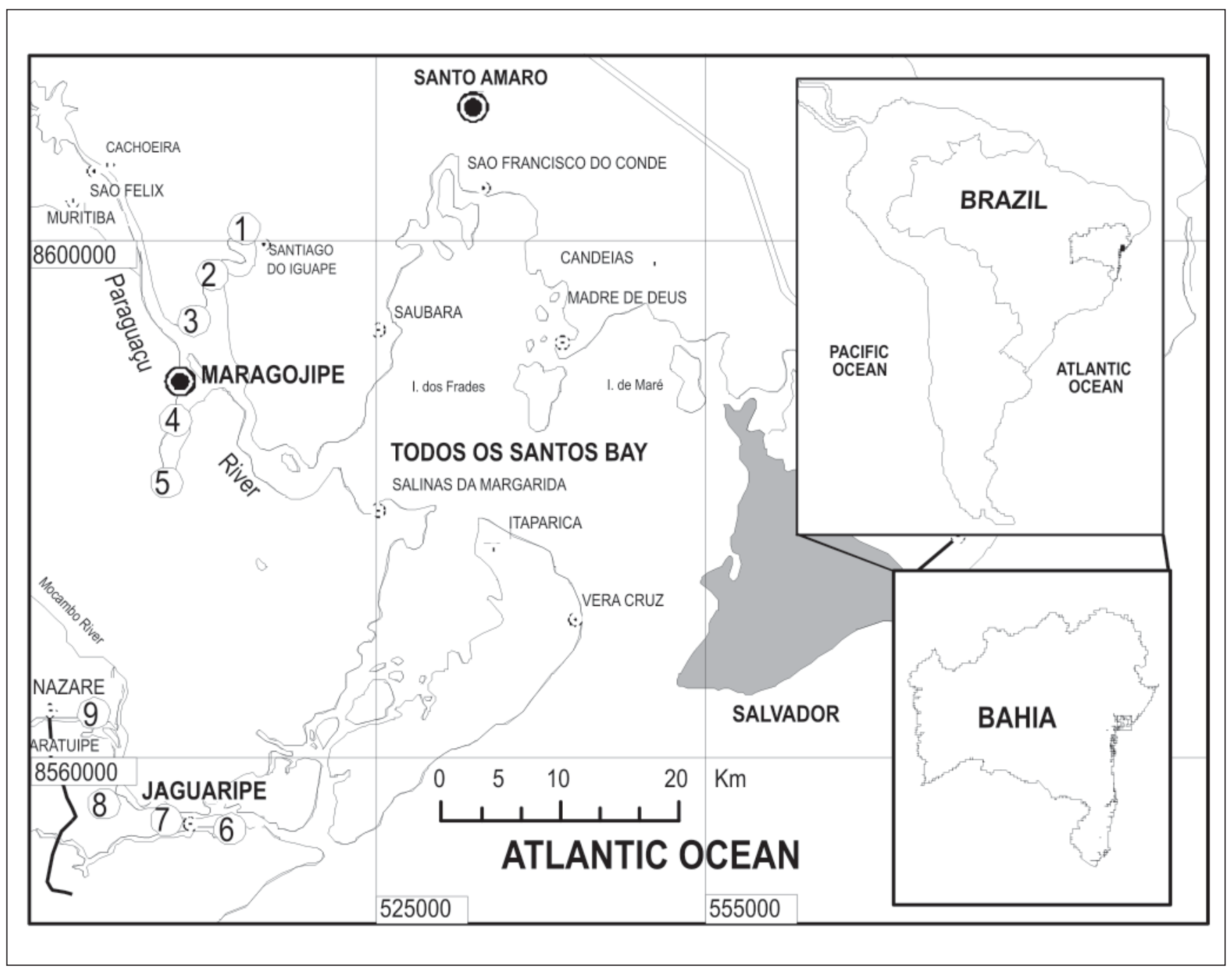

Figure 1 - Map of Todos os Santos Bay, Bahia (Brazil) indicates sampling sites of the surface water. 


\subsection{Sample treatment, extraction and analyses}

Salinity, temperature, dissolved oxygen concentration, Eh and $\mathrm{pH}$ data of the superficial water was obtained.

After returning to the laboratory, aliquots of the sample $(1.0 \mathrm{~L})$ were filtered through $0.45 \mu \mathrm{m}$ microporous filter membrane under vacuum in order to remove algae, zooplankton and suspended particles and a measured aliquot of an internal standard mixture containing naphthalene-d8, acenaphthene-d10, phenanthrene-d10 and chrysene-d12 was added to each sample. The cartridges were first conditioned with $2 \times 5 \mathrm{~mL}$ of methanol followed by $2 \times 5 \mathrm{~mL}$ of deionized water. Water samples were passed through the cartridges at a flow rate of $6 \mathrm{~mL} / \mathrm{min}$ under vacuum.

Following extraction, the cartridges were eluted with $6 \mathrm{~mL}$ of ethyl acetate, which was combined with an ethyl acetate rinse $(5 \mathrm{~mL})$ from the extraction glassware. After water was removed from the extracts by ashed $\mathrm{Na}_{2} \mathrm{SO}_{4}$, the volume of the extracts was reduced by $\mathrm{N}_{2}$ blow-down in a water bath $\left(35^{\circ} \mathrm{C}\right)$ to a final volume of $1 \mathrm{~mL}$.

The analysis was performed on a $50 \mathrm{~m}$ fused-silica column $(0.32 \mathrm{~mm}$ i.d.), coated with CPSil5-CB $(0.25 \mu \mathrm{m}$ thickness). Helium was used as the carrier gas at the flow rate of $1.5 \mathrm{~mL} \mathrm{~min}^{-1}$ (pressure $0.8 \mathrm{kPa}$ ). The following temperature program was employed: $70^{\circ} \mathrm{C}$ to $280^{\circ} \mathrm{C}$ with ramping at $4^{\circ} \mathrm{C} \mathrm{min}{ }^{-1}$. Injection and detection temperature were held at $320^{\circ} \mathrm{C}$. Detection was monitored by a flame ionization detector (FID). The structure of PAHs was confirmed by gas chromatography coupled to mass spectrometry (trace 2000 GC-MS, Thermo Finnigan, USA). A fused-silica DB-5MS capillary column $(30 \mathrm{~m} \times 0,32 \mathrm{~mm}$ i.d., $0.25 \mu \mathrm{m}$ film thickness $)$ was used. Helium with a purity of $99.999 \%$ was used as the carrier gas at a constant flow rate of $1.0 \mathrm{~mL} / \mathrm{min}$. A $2 \mu \mathrm{L}$ volume was injected by applying the hot splitless injection technique. The temperature program of the oven was started at $70^{\circ} \mathrm{C}$ (for $1 \mathrm{~min}$ ) and increased at a rate $10^{\circ} \mathrm{C} / \mathrm{min}$ to $300^{\circ} \mathrm{C}$ and was held for $10 \mathrm{~min}$. The mass spectrometer was operated in the electronic impact (EI) mode with an ion source at $200^{\circ} \mathrm{C}$ and the electron impact energy was set at $70 \mathrm{eV}$. Identification of the PAH compounds was performed by comparing GC retention time with those of authentic standards. Quantification of individual compounds was based on the comparison of peak areas with those of the recovery standards.

Before sample analysis, relevant standards were analyzed to check column performance, peak height and resolution, and the limits of detection (LOD). With each set of samples to be analyzed, a solvent blank, a standard mixture and a procedural blank were run in sequence to check for contamination, peak identification and quantification. Compounds were identified mainly by their retention times.
All data were subject to strict quality control procedures. For PAHs, deuterated IS was used to compensate for losses involved in the sample extraction and work-up. The four IS in water were determined with good precision, and their recoveries ranged from $70 \pm 5$ to $93 \pm 10 \%$ for water samples. Detection limits derived from replicate procedural blanks were approximately $0.0001 \mathrm{ng} / \mathrm{L}$. GC/MS data was acquired and processed by using the Xcalibur software.

In order to explore more latent relationships among all the stations investigated, the principal component analysis (PCA) was applied to the results obtained. PCA reduces the number of variables in the original data set into fewer factors (or principal components) without significant loss in the total variance of the data. The loading that each variable in the original data contributes to the principal components enables grouping of data with similar behaviors.

\section{Results and discussion \\ 3.1 PAH concentrations and compositional patterns}

The concentration ranges of individual and total PAHs in surface water are shown in Table 1.

The total PAH concentrations ranged from 0.0029 to $0.1079 \mathrm{ng} / \mathrm{L}$ in surface waters (main rivers, tributaries, ditches, etc.) with mean value of $0-0415 \mathrm{ng} / \mathrm{L}$ (Table 1 ). The highest concentration of surface water was observed at station S3, which is situated at the mouth where the Iguape River merges into the main river - Paraguaçu River (Figure 2).

The compositional pattern of PAH by ring size along the contamination gradient is shown in Figure 2. It is clear that two- and three-ring PAHs (naphthalene, acenaphthylene, acenaphthene, fluorine, phenanthrene and anthracene) are the most abundant PAHs, which correspond to 35 and $10 \%$ of total PAHs in surface water, respectively. In addition, four and five-ring PAHs on average correspond to 90 and $65 \%$ of total PAHs in surface water, respectively. Fluorine is one of the most frequently detected compounds in almost all of the surface water samples.

Although PAHs do not show extremely high acute toxicity towards aquatic organisms, the low molecular mass PAHs tend to be more toxic than the high molecular mass PAHs (WHO, 1998). The concentrations of PAHs in waters exceeding $10.000 \mathrm{ng} / \mathrm{L}$ suggested that the water was heavily contaminated by PAHs (WHO, 1998). A lethal concentration (LC50) as low as $10.000 \mathrm{ng} / \mathrm{L}$ has been reported for various organisms (Barron et al., 1999).

\subsection{Sources of PAHs}

The ratios of $\mathrm{Ph} / \mathrm{An}$ within the two-ring PAH group and Fl/Py within four-ring PAH group were used to differentiate 
Joil José Celino et al.

PAHs of distinct origins (Table 1): $\mathrm{Ph} / \mathrm{An}>15$ for petrogenic sources and $\mathrm{Ph} / \mathrm{An}<10$ for pyrolytic sources. Due to the wide range of values for this index found in literature, values between 10 and 15 are not considered precise relating to the source (Yang, 2000; Sanders et al., 2002).

Likewise, discrimination also occurs in the fluoranthene/ pyrene $(\mathrm{Fl} / \mathrm{Py})$ ratio, when a value greater than 1 is classically related to pyrogenic sources (Tam et al., 2001). Hence, in combination, a $\mathrm{Ph} / \mathrm{An}$ ratio value of $<10$ and $\mathrm{Fl} / \mathrm{Py}$ ratio of $>1$ indicates that the PAHs originate from pyrogenic sources
(Sanders et al., 2002). The ratios of $\mathrm{Ph} / \mathrm{An}, \mathrm{Fl} / \mathrm{Py}$ in surface water were calculated and are listed in Table 1 . As shown in Table 1, almost all the ratios of $\mathrm{Ph} / \mathrm{An}<15$ and $\mathrm{Fl} / \mathrm{Py}<1$ are indicating that the PAHs are related to petrogenic sources.

In order to explore more latent relationships among all the stations investigated, the principal component analysis (PCA) was applied to the obtained results.

Distribution of the PAHs data for surface water among the primary and secondary principal component axes is shown

Table 1 - Summary conditions of water samples were taken and range of concentrations (ng/L) of parent PAHs in surface water from the Paraguaçu and Jaguaripe Estuaries, Brazil.

\begin{tabular}{|c|c|c|c|c|c|c|c|c|c|}
\hline Station & 1 & 2 & 3 & 4 & 5 & 6 & 7 & 8 & 9 \\
\hline $\mathrm{pH}$ & 6.23 & 6.86 & 6.94 & 6.72 & 6.49 & 7.05 & 7.02 & 6.59 & 7.06 \\
\hline Eh & 56 & 15 & 17 & 35 & 35 & 19 & 17 & 30 & 25 \\
\hline Temperature $\left({ }^{\circ} \mathrm{C}\right)$ & 35 & 35 & 34 & 33 & 36 & 29 & 30 & 30 & 29 \\
\hline Salinity (\%o) & 30 & 29 & 30 & 34 & 31 & 35 & 30 & 24 & 20 \\
\hline D.O. (mg/l) & 5.4 & 7.3 & 6.3 & 4.8 & 3.5 & 5.8 & 4.9 & 6.1 & 3.4 \\
\hline $\mathrm{Np}$ & 0.0023 & 0.0009 & 0.0015 & 0.0019 & 0.0012 & 0.0017 & 0.0011 & 0.0009 & 0.0016 \\
\hline $\mathrm{mNp}$ & 0.0010 & 0.0000 & 0.0003 & 0.0011 & 0.0020 & 0.0000 & 0.0007 & 0.0004 & 0.0006 \\
\hline $\mathrm{dNp}$ & 0.0000 & 0.0001 & 0.0037 & 0.0003 & 0.0034 & nd & nd & 0.0000 & 0.0001 \\
\hline Acy & 0.0001 & 0.0002 & 0.0002 & 0.0004 & 0.0002 & 0.0001 & 0.0000 & 0.0009 & 0.0001 \\
\hline Ace & 0.0003 & 0.0003 & 0.0000 & 0.0001 & 0.0004 & 0.0000 & 0.0000 & 0.0000 & 0.0000 \\
\hline $\mathrm{F}$ & 0.0010 & 0.0013 & 0.0013 & 0.0011 & 0.0021 & 0.0014 & 0.0014 & 0.0015 & 0.0012 \\
\hline $\mathrm{Ph}$ & 0.0027 & 0.0015 & 0.0010 & 0.0010 & 0.0014 & 0.0011 & 0.0011 & 0.0013 & 0.0015 \\
\hline An & 0.0031 & 0.0017 & 0.0013 & 0.0009 & 0.0021 & 0.0013 & 0.0013 & 0.0018 & 0.0020 \\
\hline $\mathrm{FI}$ & 0.0034 & 0.0010 & 0.0570 & 0.0019 & 0.0220 & 0.0014 & 0.0014 & 0.0036 & 0.0195 \\
\hline Py & 0.0066 & 0.0026 & 0.0065 & 0.0009 & 0.0015 & 0.0014 & 0.0014 & 0.0088 & 0.0192 \\
\hline $\mathrm{BaAn}$ & nd & nd & 0.0055 & nd & 0.0159 & nd & nd & 0.0015 & 0.0066 \\
\hline Chry & nd & nd & 0.0131 & nd & 0.0145 & nd & nd & 0.0006 & 0.0029 \\
\hline $\mathrm{BbFI}$ & nd & nd & nd & nd & nd & nd & nd & nd & nd \\
\hline $\mathrm{BkFI}$ & nd & nd & nd & nd & nd & nd & nd & nd & nd \\
\hline BaPy & nd & 0.0592 & 0.0164 & nd & 0.0235 & 0.0334 & nd & nd & 0.0333 \\
\hline Total PAH & 0.0205 & 0.0689 & 0.1079 & 0.0098 & 0.0902 & 0.0415 & 0.0085 & 0.0213 & 0.0886 \\
\hline PAH LMM & 0.0105 & 0.0060 & 0.0093 & 0.0069 & 0.0128 & 0.0052 & 0.0056 & 0.0067 & 0.0071 \\
\hline PAH HMM & 0.0101 & 0.0629 & 0.0986 & 0.0028 & 0.0774 & 0.0364 & 0.0028 & 0.1450 & 0.0815 \\
\hline $\mathrm{Ph} / \mathrm{An}$ & 0.8858 & 0.9271 & 0.7652 & 1.1694 & 0.6407 & 0.5399 & 0.8083 & 0.7162 & 0.7817 \\
\hline $\mathrm{BaAn} /(\mathrm{BaAn+Chry)}$ & $\mathrm{nc}$ & $\mathrm{nc}$ & 0.2967 & $\mathrm{nc}$ & 0.5240 & $\mathrm{nc}$ & $\mathrm{nc}$ & 0.7182 & 0.6962 \\
\hline $\mathrm{F} /(\mathrm{F}+\mathrm{Py})$ & 0.3409 & 0.2841 & 0.8981 & 0.6694 & 0.9378 & 0.4906 & 0.5142 & 0.2900 & 0.5040 \\
\hline $\mathrm{An} /(\mathrm{Na}+\mathrm{Ph})$ & 0.5303 & 0.5189 & 0.5665 & 0.4610 & 0.6095 & 0.6494 & 0.5530 & 0.5827 & 0.5613 \\
\hline
\end{tabular}

$\mathrm{nd}=$ not delected $\quad \mathrm{nc}=$ not calculated 


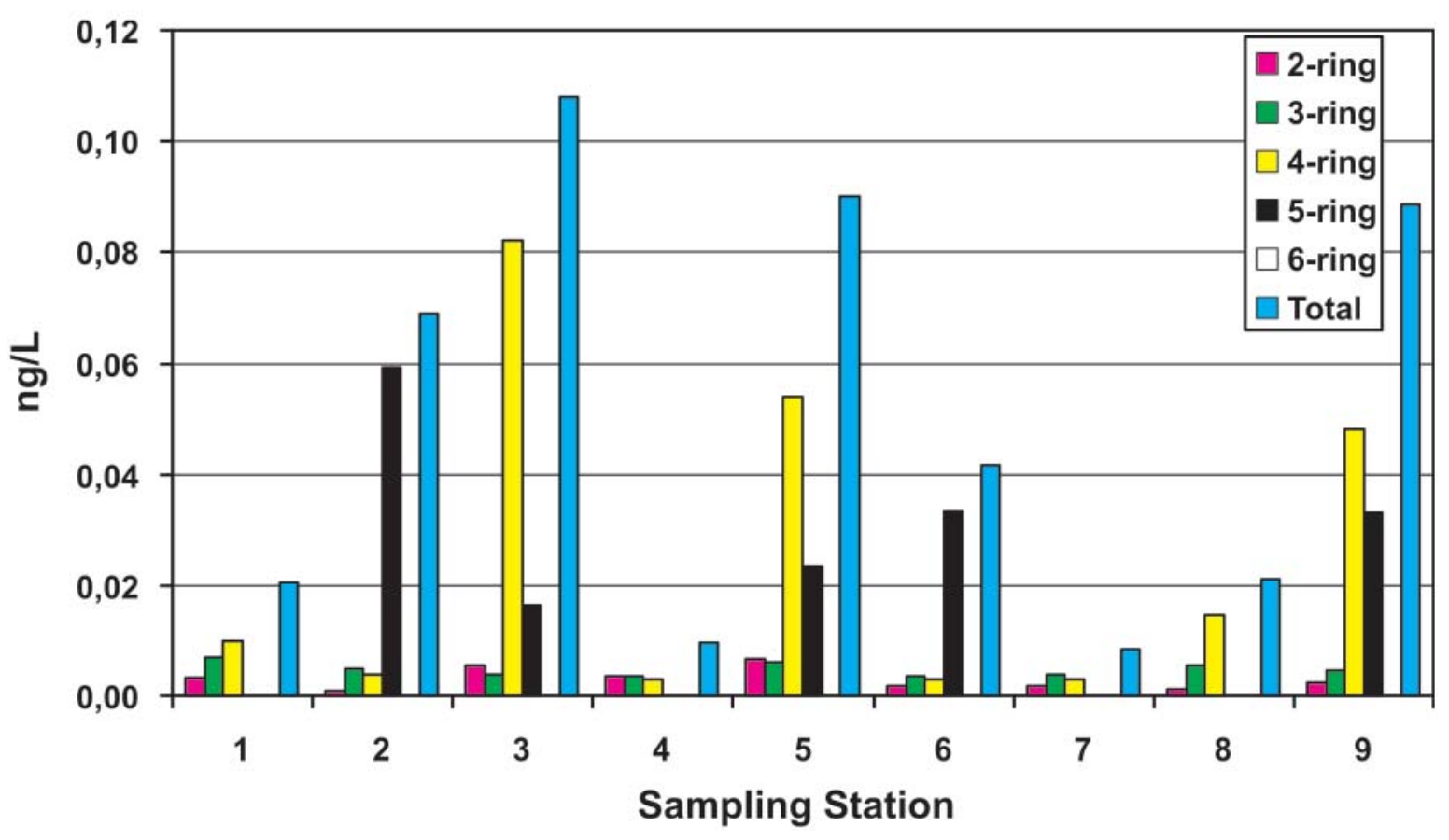

Figure 2 - Concentrations of two to six-ring and total PAHs in the surface water of the Paraguaçu and Jaguaripe rivers. Two-ring PAHs include naphthalene; three-ring PAHs include acenaphthylene, acenaphthene, fluorine, phenanthrene and anthracene; four-ring PAHs include fluoranthene, pyrene, benzo[a]anthracene and chrysene; five-ring PAHs include benzo[b]fluoranthene, benzo[k]fluoranthene, benzo[a]pyrene and dibenzo[a,h]anthracene; six-ring PAHs include indeno[1,2,3-c,d]pyrene and benzo[g,h,i]perylene.

in Figure 3. The two principal components selected are able to account for $51 \%$ of total variance of the original data. The first and second PCs in surface water represented $29 \%$ and $22 \%$ of the variability, respectively.

There are three groups discriminated on the factor loading plot (Figure 3A). Group A clusters samples of stations 1 and 9; group B, samples collected from stations 3 and 5; group C contains samples collected from stations 2,4 and 6 to 8 . The discrimination in three groups was confirmed by hierarchical clustering analysis (HCA), using complete linkage and Euclidean distances.

As shown in Figure 3A, group A is characterized by the negative axes of both principal components; on the other hand, from Figure 3B, this quadrant is dominated by phenanthrene. It indicated that phenanthrene contributed significantly to the samples in group A, and the prominent contribution of phenanthrene over the contribution of the other PAHs was notable.

The samples in group B got their contribution mostly from fluorine, which dominated the PAHs. However, compared with group A, the samples in group B gave a relatively high contribution to factor 2 . This conclusion can be confirmed by Figure 3B.

\section{Conclusions}

The PAH profiles for the water samples revealed that the dominant PAHs were low molecular weight (two- and three ring) PAHs in a surface water aquatic environment including naphthalene, acenaphthylene, acenaphthene, fluorine, phenanthrene and anthracene.

The PAHs in surface water samples originated mainly from petrogenic inputs based on the high proportion of two-ring (naphthalene) and three-ring PAHs. Although the calculated ratios of $\mathrm{Ph} / \mathrm{An}, \mathrm{Fl} / \mathrm{Py}$ and principal component analysis are usually performed to analyze the origin of PAHs in sediments, we attempted to apply the ratios and PCA to the surface water in this study. The analysis results showed that the ratios and PCA could be applied to surface water investigation to some extent.

Oil spill and leakage from boats and ships, vehicular exhaust emission, discharge from municipal and industrial wastewater and runoff might be important sources. It indicates that surface water received anthropogenic PAHs from different sources and although specific sources are known to be responsible for the presence of PAHs in surface waters, their occurrence cannot always be related to a particular source. This indicates that the studied area doesn't show any modern 
environmental impact and that it can be used as a background in order to identify the typical geochemical signature of non-impacted ecosystems in Todos os Santos Bay, Brazil.

\section{Acknowledgements}

This research project was supported by the financial help of the Brazilian Science and Technology Ministry Project FINEP - CT-PETRO ${ }^{\circ}$ 640002700. JJC wishes to thank the Research Foundation of the State of Bahia - FAPESB - for granting him a research scholarship n 297/2007.

\section{Bibliographic references}

BARRON, M.G., PODRABSKY, T., OGLE, S., RICKER, R.W. Are aromatic hydrocarbons the primary determinant of petroleum toxicity to aquatic organisms? Aquat. Toxicol., v. 46, p. 253-268, 1999.

BAUMARD, P., BUDZINSKI, H., GARRIGUES, P. Analytical procedure for the analysis of PAHs in biological tissues by gas chromatography coupled to mass spectrometry: application to mussels. Fresenius J. Anal. Chem., v. 359, p. 502-509, 1997.

BRUN, G.L., VAIDYA, O.M., L'EGER, M.G. Atmospheric deposition of polycylic aromatic hydrocarbons to Atlantic, Canada: geographic and temporal distributions and trends 1980 2001. Environ. Sci. Technol., v. 38, p. 1941-1948, 2004.

CELINO, J.J., QUEIROZ, A.F.de S. Fonte e grau da contaminação por hidrocarbonetos policíclicos aromáticos (HPAs) de baixa massa molecular em sedimentos da baía de Todos os Santos, Bahia. REM - Revista Escola de Minas, Ouro Preto, v. 59, n. 3, p. 265-270, 2006.

CEPLAB (Centro de Planejamento da Bahia). Bacias Hidrográficas do Estado da Bahia. Série Recursos Naturais. Salvador: Governo do Estado da Bahia, 1979. 190p.

CETESB (Companhia de Tecnologia de Saneamento Ambiental). Poluição das águas na baía de Santos e estuários de Santos e São Vicente. 1979. (Relatório Técnico).
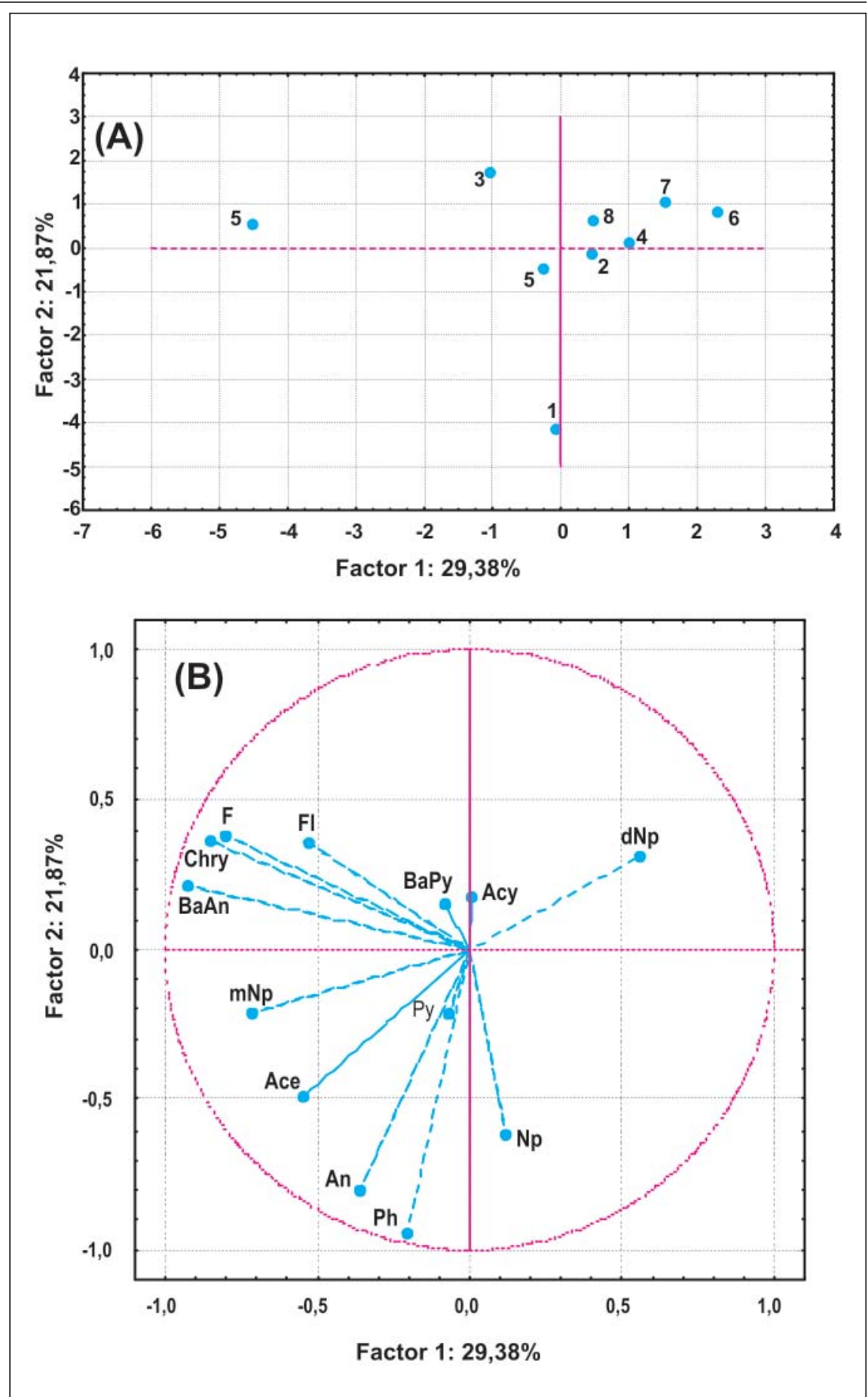

Figure 3 - PCA showing the pattern of PAHs in the surface water: (A) factor loading plot and (B) factor score plot. (Np) naphthalene, (Acy) acenaphthylene, (Ace) acenaphthene, (F) fluorine, $(\mathrm{Ph})$ phenanthrene, (An) anthracene, (FI) fluoranthene, $(\mathrm{Py})$ pyrene, $(\mathrm{Ba})$ benzo[a]anthracene, (Chy) chrysene, $(\mathrm{BbFl})$ benzo[b]fluoranthene, (BkFI) benzo[k]fluoranthene, $(\mathrm{BaP})$ benzo[a] pyrene and (dAn) dibenzo[a,h]anthracene.

CETESB (Companhia de Tecnologia de Saneamento Ambiental). Metais pesados na baía de Santos e estuários de Santos e São Vicente. 1981. (Relatório Técnico).

CETESB (Companhia de Tecnologia de Saneamento Ambiental). Contaminantes na bacia do rio Cubatão e seus reflexos na biota aquática. 1990. (Relatório Técnico). 
CETESB (Companhia de Tecnologia de Saneamento Ambiental). Relatório Sistema Estuarino Santos São Vicente. Agosto de 2001. Available from <www.cetesb.sp.gov.br/Agua/agua_geral. asp/>; 2001.

CLEMONS, J.H., ALlAN, L.M., MARVIN, C.H., WU, Z., MCCARRY, B.E., BRYANT, D.W. Evidence of estrogen- and TCDD-like activities in crude and fractionated extracts of PM10 air particulate material using in vitro gene expression assays. Environ. Sci. Technol., v. 32, p. 1853-1860, 1998.

CRA (Centro de Recursos Ambientais). Diagnóstico do grau de contaminação da baía de Todos os Santos por metais pesados e hidrocarbonetos de petróleo a partir da análise das suas concentrações nos sedimentos de fundo e na biota associada. 2004. (Relatório Técnico).

LEÃO, Z.M.A.N., DOMINGUEZ, J.M.L. Tropical coast of Brazil. Marine Pollution Bulletin. n. 41, p. 112-122, 2000.

LESSA, G.C., DOMINGUEZ, J.M.L., BITTENCOURT, A.C.S.P., BRICHTA, A. The tides and tidal circulation of Todos os Santos Bay, Northeast Brazil: a general characterization. An. Acad. Bras. Cienc., v. 73, n. 2, p. 246-261, 2001

MAGI, E., BIANCO, R., IANNI, C., CARRO, M.D. Distribution of polycyclic aromatic hydrocarbons in the sediments of the Adriatic Sea. Environ. Pollut., v. 119, p. 91-98, 2002

MANOLI, E., SAMARA, C. Polycyclic aromatic hydrocarbons in natural waters: sources, occurrence and analysis. Trends Anal. Chem., v. 18, p. 417-428, 1999.

MANOLI, E., SAMARA, C., KONSTANTINOU, I., ALBANIS, T. Polycyclic aromatic hydrocarbons in the bulk precipitation and surface waters of northern Greece. Chemosphere, v. 41, p. 1845-1855, 2000.

MASTRAL, A.M., CALL'En, M.S. A review on polycyclic aromatic hydrocarbon (PAH) emissions from energy generation. Environ. Sci. Technol., v. 34, p. 3051-3057, 2000.
SANDERS, M., SIVERTSEN, S., SCOTT, G. Origin and distribution of polycyclic aromatic hydrocarbon in superficial sediments from the Savannah River. Arch. Environ. Contam. Toxicol., v. 43, p. 438-448, 2002.

SCHUBERT, P., SCHANTZ, M.M., SANDER, L.C., WISE, S.A. Determination of polycyclic aromatic hydrocarbons with molecular weight 300 and 302 in environmental-matrix standard reference materials by gas chromatography/mass spectrometry. Anal. Chem., v. 75, p. 234-246, 2003

SZOLAR, O.H.J., ROST, H., BRAUN, R., LOIBNER, A.P. Analysis of polycyclic aromatic hydrocarbons in soil: minimizing sample pretreatment using automated soxhlet with ethyl acetate as extraction solvent. Anal. Chem., v. 74, p. 2379-2385, 2002.

TAM, N.F.Y., KE, L., WANG, X.H., WONG, Y.S. Contamination of polycyclic aromatic hydrocarbons in surface sediments of mangrove swamps. Environ. Pollut., v. 114, p. 255-263, 2001.

VEIGA, I.G. Avaliação da origem dos hidrocarbonetos em sedimentos superficiais de manguezais da região norte da baía de Todos os Santos, Bahia. Laboratório de Engenharia e Exploração de Petróleo - LENEP/UENF, 2003. 205p. (Dissertação de Mestrado).

WHO. Polynuclear aromatic hydrocarbons. Guidelines for DrinkingWater Quality, second ed., addendum to vol. 2, Health Criteria and Other Supporting Information, World Health Organization, Geneva, 1998, p. 123-152.

Wolgemuth, K.M., BURnetT, W.C., MOURA, P.L. Oceanography and suspended material in Todos os Santos Bay. Rev. Bras. Geoc., v. 11, n. 3, p. 172-178, 1981.

YANG, G.P. Polycylic aromatic hydrocarbons in the sediments of the South China Sea. Environ. Pollut., v. 108, p. 163-171, 2000.

Artigo recebido em 08/04/2008 e aprovado em 21/10/2009.

\title{
A
}

\section{Rem}

\section{tem novo endereço eletrônico para submissão de artigos:}

\section{http://submission.scielo.br/index.php/rem/index}

\author{
www.rem.com.br
}

